\title{
A Closer Link between Politics and the Scientific Community, as well as Global Coordination are Essential to Tackle Environmental Collapse
}

\section{Mauro Lenzi*}

Lagoon Ecology and Aquaculture Laboratory (LEALab), Orbetello Pesca Lagunare Company, Via G. Leopardi 9, 58015 Orbetello, Italy

I think our greatest challenge this century will be to forge collaboration between the spheres of science and politics. This may appear to exist already - many experts are called by public bodies and local government to give opinions, conduct studies, etc. - but while money is spent on studies, then filed away in cabinets, subsequent decisions are often dictated by social pressure and do not always go in the right direction for correct environmental management and renewal of resources.

This is not to say that politics must be replaced by technobureaucracy: it must always be free, because the risk would be a drift of democracy towards an ideological rigidity, even if it brought by the scientific community. However, decisions about projects that might have heavy environmental consequences can no longer be free. Coordination is clearly needed at high levels because the effects of administrative decisions, especially in the field of economic policy and land management, are increasingly far-reaching and may affect vast geographical areas distant from each other.

Let us consider a few examples. First of all, global warming has a whole cascade of effects, such as extreme weather events, desertification, flooding and violent storms, which impinge on biodiversity, water resources, forestry, fauna and food production. If it is not too late, avoiding this problem will be extremely difficult because it means putting the brakes on certain business/financial sectors and modifying the paths of developing countries. The scientific community needs to show greater internal coherence and cannot remain divided regarding the risks facing the planet [1]. This division is exploited by industrial interests wishing to maintain the status quo. There is no rational planning of development. Certain territory must be protected from the effects of economic enterprise, even if this may penalise or seem to penalise it. Firms should establish in places that can sustain them. This is a difficult concept to translate into political action.

A second example is aquaculture. Mediterranean and north Atlantic fish farms that produce essentially carnivorous fish use feedstock containing fish meal produced with by-catch from overfishing in the north Atlantic or south Pacific. Trade in live fish increases the spread of allochthonous species and diseases that can affect natural fish populations, fisheries and fish-farms themselves.

Regulation at world level is long overdue. Intensive aquaculture should be radically redesigned and should concentrate on more sustainable species; this can also be promoted through education of consumers. However, it requires political coordination at world level and agreement among the scientific community, which is still divided between those working on reducing the energy profligacy of fish farming [2] and those who continue to concentrate on the extremely dissipative farming of carnivorous species, also a source of eutrophication [3]. Such coordination could harm free enterprise but is essential for survival of the increasingly numerous underfed population of the world.

In Italy fish farms have often been established near or even on top of seagrass meadows (Posidonia oceanica).Damage to these meadows leads to coastal erosion [4]. To remedy sand loss, which affects tourism and bathing (major and often the only sources of income for some communities), sand has been obtained a few hundred metres offshore, favouring further erosion in rough weather.

By contrast, even scientists can contribute to confusion. An example is scientists' exaggeration of the possible effects of allochthonous species and their failure to consider the context of already degraded environmental conditions. For example, Caulerpa racemosa v. cilindracea was initially considered dangerous for autochthonous Mediterranean populations [5,6] because it quickly invades many environments. We now know that it regresses as soon as environmental resilience restores original conditions of these degraded environments [7-9]. Though I have no scientific data to demonstrate it, I think the same may be true of the red swamp crayfish Procambarus clarkii, native to the south Atlantic coasts of the USA. This crayfish has invaded many parts of Europe [10], all of which, however, were already degraded and without the necessary predators. The same may be true of Carcinus maenas and C. aestuarii, this time from Europe [11,12], which have invaded the coasts of America. Such errors of assessment have cost energy and resources that could have been directed elsewhere, above all in "thin cow" periods.

Though knowledge should be wide-ranging, unnecessary alarm should be avoided as it damages scientific credibility with the general public. This is a problem that also involves scientific journals, which should be more selective and make a more rigid peer-reviewed. Furthermore to decide which research to fund, I think administrators should be guided by a specific evaluation council with frequent turnover among council members; to avoid cronyism.

\section{References}

1. Goudarzi S (2006) Global Worming or Just Hot Air? A Dozen Different View.

2. Soto D, Aguilar-Manjarrez J, Hishamunda N (2008) Building an ecosystem approach to aquaculture. FAO Fisheries and Aquaculture Proceedings.

3. Pearson TH, Black KD (2001) Environmental impact of aquaculture. Sheffield Academic Press, UK

4. Gacia E, Duarte CM (2001) Sediment Retention by a Mediterranean Posidonia oceanica Meadow: The Balance between Deposition and Resuspension. Estuarine Coastal and Shelf Science 52: 505-514.

5. Ceccherelli G, Piazzi L, Balata D (2002) Spread of introduced Caulerpa species in macroalgal habitats. J Experimental Marine Biology and Ecology 280: 1-11.

*Corresponding author: Lenzi M, Lagoon Ecology and Aquaculture Laboratory (LEALab), Orbetello Pesca Lagunare Company, Via G. Leopardi 9, 58015 Orbetello, Italy, Tel: +39 3487 304274; E-mail: lealab1@gmail.com

Received March 14, 2015; Accepted March 17, 2015; Published April 30, 2015

Citation: Lenzi M (2015) A Closer Link between Politics and the Scientific Community, as well as Global Coordination are Essential to Tackle Environmental Collapse. J Aquac Res Development 6: 335. doi:10.4172/2155-9546.1000335

Copyright: (c) 2015 Lenzi M. This is an open-access article distributed under the terms of the Creative Commons Attribution License, which permits unrestricted use, distribution, and reproduction in any medium, provided the original author and source are credited. 
Citation: Lenzi M (2015) A Closer Link between Politics and the Scientific Community, as well as Global Coordination are Essential to Tackle Environmental Collapse. J Aquac Res Development 6: 335. doi:10.4172/2155-9546.1000335

Page 2 of 2

6. Piazzi L, Ceccherelli G (2006) Persistence of biological invasion effects: Recovery of macroalgal. Estuarine, Coastal and assemblages after removal of Caulerpa racemosa var. cylindracea. Shelf Science 68: 455-461.

7. Lenzi M, Birardi F, Finoia MG (2013) Can the marine ecosystem of a Posidonia oceanica barrier reef react and defend itself against the spread of Caulerpa racemosa var. cylindracea?. International Journal of Marine Science 3: 158-165.

8. Gennaro P, Piazzi L (2014) The indirect role of nutrients in enhancing the invasion of Caulerpa racemosa var. cylindracea. Biol Invasions 16: 1709-1717.

9. Piazzi L, Gennaro P, Ceccherelli G (2014) The role of anthropocenic stressor in facilitating the spread of Caulerpa racemosa var. cylindracea.
10. Grosholz R, Ruiz GM (1996) Predicting the impact of introduced marine species: Lessons from the multiple invasions of the European green crab Carcinus maenas. Biological Conservation 78: 56-66

11. Carlton JT, Cohen AN (2003) Episodic global dispersal in shallow water marine organisms: the case history of the European shore crabs Carcinus maenas and C. aestuarii. J Biogeography 30: 1809-1820.

12. Gherardi F (2006) Crayfish invading Europe: the case study of Procambarus clarkii. Marine and Freshwater Behaviour and Physiology 39: 175-191. 